\title{
Synthesis of Neplanocin A Analog with 2'-"up"-C-Methyl Substituent as Potential Anti-HCV Agent
}

\author{
Hyung-Rock Lee, Jin-Ah Kang, Ah-Young Park, Won Hee Kim, Pusoon Chun, Jungsu Kim, Jin-Ah Kim, \\ Boeun Lee, ${ }^{+}$Lak Shin Jeong, ${ }^{+}$and Hyung Ryong Moon \\ Laboratory of Hedicinal Chemistry, College of Pharmacy and Research Institute for Drug Development, \\ Pusan National Lniversin, Busan 609-735. Korea. "E-mail. mhrlosiápusan ac.kr \\ ${ }^{\dagger}$ College of Pharmacy, Seoul National Lntwersity, Seoul 151-7t2, Korea \\ 'Laboratorv of Medicinal Chemistry, College of Pharmacv. Ewha Womans Cniversin, Seoul 120-750, Korea \\ Recerved Jine 23, 2009, Accepted July 31, 2009
}

\begin{abstract}
2'- $\beta-C-$-Methylneplanocin A (3) was synthesized via 2- $\beta-C$-methyylribonolactone, prepared by a modified Whistler and BeMiller's method developed by our laboratory, as potential anti-HCV agent. Reduction of 14 with Dibal-H afforded $\mathbf{2 6}$ in a good yield with a trace of $\mathbf{2 5}$, whereas a Luche reduction gave $\mathbf{2 6} / \mathbf{2 5}=4 / 1$ mixture. Several attempts were made to chemoselectively remove TBS group in the presence of TBDPS group and treatment with both PPTS and TsOH showed the best result. Condensation of 26 with 6-chloropurine under Mitsunobu conditions produced an $\mathrm{S}_{\wedge} \cdot 2$ product 27 along with an $\mathrm{S}_{\wedge} \cdot 2^{\prime}$ product 28
\end{abstract}

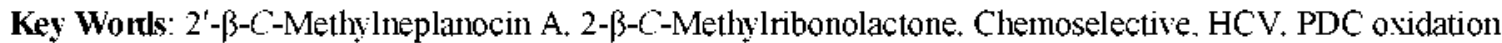

\section{Introduction}

Hepatitis C virus (HCV), which was identified first in 1989 as a single-stranded, enveloped. positive sense RNA virus ${ }^{1}$ and which is a major causative virus of chronic liver disease. has infected an estimated 170 million people worldwide.- To date, there is no vaccine available against $\mathrm{HCV}$. The monotherapy with pergylated IFN- $\alpha$ (interferon alpha) and the combination therapy with pergylated IFN- $\alpha$ and ribavirin were approved by FDA for the treatment of HCV infection. ${ }^{3.4}$ However, ribavirin causes side effects such as anemia and pergy lated IFN- $\alpha$ does neuropsy chiatirc adverse effects. ${ }^{3}$ Judged from these adverse effects and an ability of viruses easily obtaining resistance to the drugs. there are urgent requirements to discover new and more effective anti-HCV agents.

Recently. 2 '- $\beta-C$-methylribonucleoside derivatives including $2{ }^{\prime}-\beta-C$-methyladenosine (Fig. 1. $\mathrm{EC}_{5 \mathrm{D}}=0.3 \mu \mathrm{M}$ in a cell-based. subgenomic HCV replicon assay) have been reported to exhibit very potent activity against HCV. Currently, valopicitabine, ${ }^{6}$ a prodrug of 2 - $\beta$-C-methylcytidine. is in Phase II clinical trials for the treatment of HCV infection. It is reported that these nucleosides act as a terminator of the growing HCV's RNA chain. After the discovery of 2 '- $\beta-C$-methyladenosine, numerous medicinal chemists have concentrated their attention on the șinthesis of nucleosides with a branched sugar to find new anti-HCV agents.

$2 '-\beta$-C-Methy ladenosine was reported to display a strong preference for a north conformation ( $P=15.6^{\circ}$ in pseudorotational cycle). which is one of two conformations that normal bicyclo [3.1.0]hexyl nucleosides can adopt. On the basis of the fact, recently we have sy nthesized north-bicyclo [3.1.0] hexyl nucleoside. 1, with $2^{\prime}-\beta-C$-methyl group. Disappointingly. it did not show any significant anti-HCV activity, indicating that cellular kinases might prefer a south conformation to the north conformation for conversion to the corresponding nucleotides.
It is well known that neplanocin A is a naturally occurring product possessing potent anticancer and antiviral activities. Fluoroneplanocin $\mathrm{A}^{(1)}$ and its cytosine congener $2^{11}$ exhibited more potent anticancer and antiviral activities. Considering that neplanocin A and its fluoro-substituted analogues showed good biological activities. the cyclopentene template of these nucleosides can be assumed to be a good template for phosphory lations by kinases. Therefore. as part of our continued effort to discover more potent $\mathrm{HCV}$ inhibitors. ${ }^{1 \hat{2}}$ it was of great interest to synthesize neplanocin A derivative with $2^{\prime}$ $\beta-C$-methyl substituent. We wish to report herein the synthesis of $2^{\prime}-\beta-C$-methy lneplanocin A (3).

\section{Results and Discussion}

First of all. attempts were made to directly introduce a methyl substituent on the cyclopentenone teniplate of 4 by a<smiles></smiles>

2'-3-C-Methyladenosine

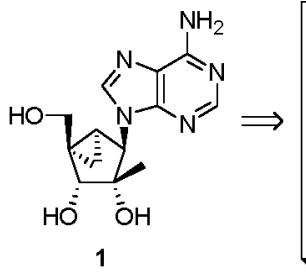

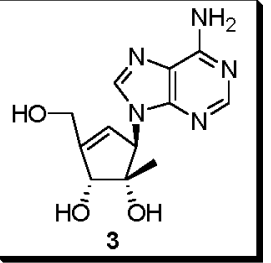

D<smiles>Nc1ncnc2c1ncn2[C@@H]1C[C@@H](O)[C@@H](O)[C@H]1O</smiles>

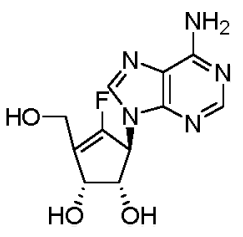

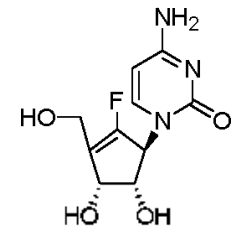

Neplanocin A

2

Figure 1. The rationale for the design of the desired nucleoside, 3 . 
base-catalyzed methylation and following sequential procedures: i) stereoselective hy'droxymethylation ${ }^{13}$ using a ClaisenSchmidt reaction ii) tosylation of the resulting hydroxỵl group and iii) reduction of the tosylate ${ }^{1+}$ (Scheme 1). But, these reactions did not give any alkỵlated product.<smiles>CC1(C)O[C@@H]2C(=O)C=C(COBr)[C@@H]2O1</smiles>
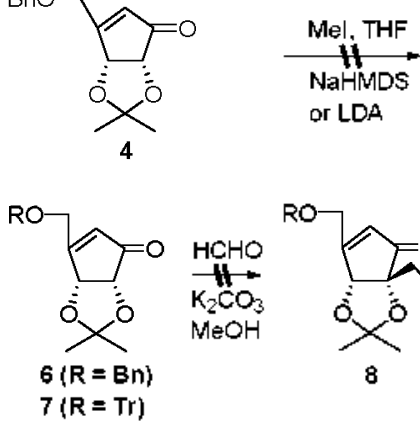

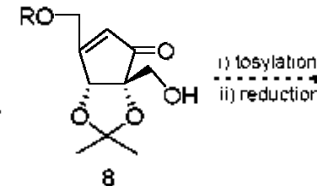

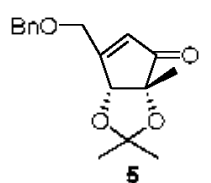

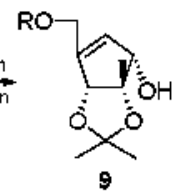

Scheme 1. Attempts for introduction of methyl substituent into 5- $\beta$ position of crclopentenone/cyclopentenol

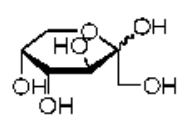

D-(-)fructose

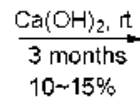

$10-15 \%$

*Whistler and Bemiller's Method

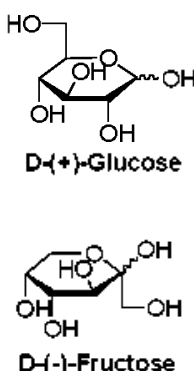

D-(-)-Fructose

*Fleet's Method

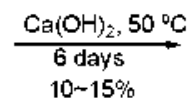

$10-15 \%$

$\mathrm{Me}_{2} \mathrm{NH}, \mathrm{EtOH}$ $\mathrm{ACOH}$

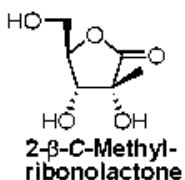

ribonolactone
$\mathrm{Ca}(\mathrm{OH})_{2}$

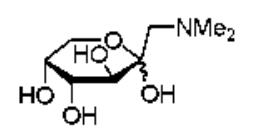

* Modified Whistler and BeMiller's Method

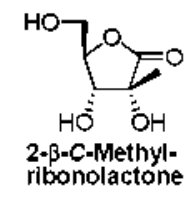

2- $\beta-C-$-Methyl-

Scheme 2. Synthetic methods for D-2- $\beta-C_{-}-$methylribono-1,4-lactone
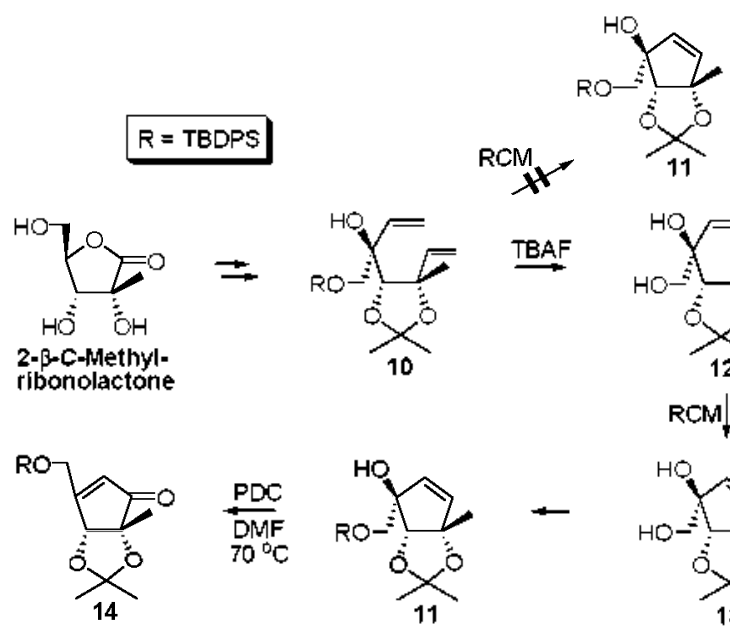

Scheme 3. Svnthetic method for 5-methylcyclopentenone 14 vic an oxidative rearrangennent using PDC
Thus. 2- $-\beta-C$-methy lribonolactone. already bearing $2-\beta-C$ methyl substituent. was used as key material. instead of the introduction of methyl substituent into cyclopentene template. First synthesis of $2-\beta-C$-methylribonolactone was reported by Whistler and BeMiller (Scheme 2). ${ }^{15}$ but too long reaction time was required and the yield was also low $(10-15 \%)$. Due to these defects. new synthetic method has been required continuously. Recently, Fleet and coworkers reported a novel synthesis of 2- $\beta-C$-methylribonolactone starting from D-glucose (Scheme 2). ${ }^{16}$ but the desired product was obtained in a less than $5 \%$ yield although $19 \%$ yield was reported in the literature. Therefore. our laboratory has developed a modified Whistler and BeMiller's method. which decreased the reaction time from three months to $6 \mathrm{~d}$ and gave a similar yield to that of the Whistler and BeMiller's method (Scheme 2). 2- $\beta$ C-Methyllibonolactone was obtained in $15 \%$ yield by treatment of D-fnictose with $\mathrm{Ca}(\mathrm{OH})_{2}$ at an elevated temperature $\left(50^{\circ} \mathrm{C}\right)$ for $6 \mathrm{~d}$

It was err isioned that 5- $\beta-C-$-methylcyclopentenone 14 (Scheme 3) would be an appropriate internediate for the synthesis of $2^{\prime}-\beta-C$-methy lneplanocin A (3). Attempts were made to use an oxidative rearrangement reaction with $\mathrm{PDC}$ for the synthesis of 14 (Scheme 3). First. in order to synthesize the substrate 11 for the oxidative rearrangement reaction. ring-closing metathesis (RCM) ${ }^{17}$ with diene 10, prepared from 2- $\beta-C$-methylribonolactone. was employed. but afforded only a trace of 11 along with the unreacted diene $\mathbf{1 0}$. The low reactivity of the RCM reaction might be attributed to a steric lindrance between the bulky TBDPS and isopropylidene groups. Therefore a RCM reaction was again conducted with TBDPS-deprotected diene 12. and the desired RCM product. 13 was produced in a high yield within $2 \mathrm{~h}$. A PDC-mediated oxidative rearrangement reaction ${ }^{18}$ with 11 , obtained from silyation of 13 . gave the desired product in $50 \%$ yield along with unreacted starting material $(41 \%)$. which has a quite similar $R_{f}$ value to that of the product even if various combinations of several solvents were used as the developing solvent. This indicates that there is a difficulty in the purification unless the reaction proceeds completely:

Method to by pass the troublesome oxidative rearrangement step was attempted as the next approach to the synthesis of 5$\beta$ - $C$-methylcyclopentenone 14. Conversion of 2- $\beta$ - $C$-methylribonolactone into a glycosyl donor 26 via $\mathbf{1 +}$ is described in Scheme 4. Isopropylidenation followed by silylation produced silyl ether 16. which was reduced by successive two reducing reagents (Dibal-H and $\mathrm{NaBH}_{4}$ ) to give diol 18 in a good yield. A TBS group was chosen for the regioselective protection of prinary hydroxyl group and the reaction proceeded with a quantitative yield. Swern oxidation of the remaining hydroxyl group of $\mathbf{1 9}$ followed by a Wittig reaction of the resulting ketone $\mathbf{2 0}$ with (methylidene)triphenyl phosphorane afforded 21 in a good yield without any epimerization. ${ }^{19}$ To carry out the selective deprotection of TBS group of 21 in the preselice of TBDPS group. ${ }^{20}$ first. $\mathrm{LiCl} . \mathrm{H}_{2} \mathrm{O}$ and DMF were treated. ${ }^{31}$ but the yield and reaction time were unsatisfactory (Table 1). Secondly, $\mathrm{CeCl}_{3}$ and $\mathrm{NaI}$ in $\mathrm{CH}_{3} \mathrm{CN}$ were employed." Although at an elevated temperature $\left(50^{\circ} \mathrm{C}\right)$. the desired product was obtained, the yield was too low and the major product was a diol compound. generated from removal of both TBDPS and TBS groups. In case of treat- 

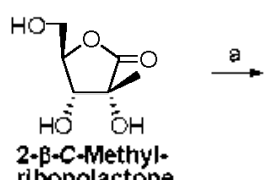<smiles>CC1(C)OC23OC(=O)OC2(CO)OC13</smiles><smiles>[R9]C1OC(=O)C2OC(C)(C)OC12</smiles>

$\stackrel{d}{\longrightarrow}$

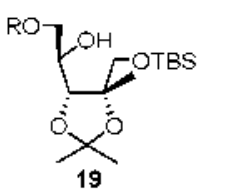

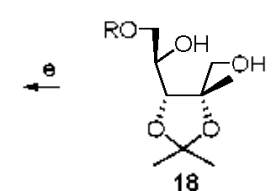

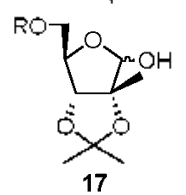

f)

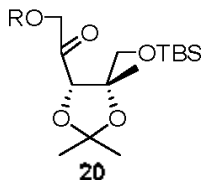

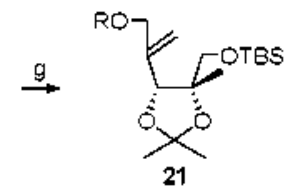

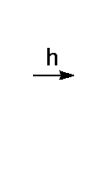

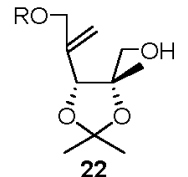
1)

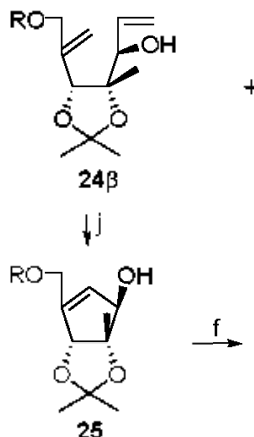

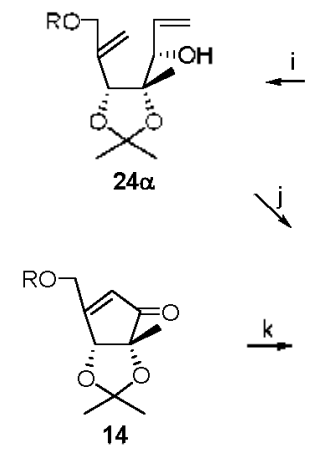

Table 1. Selective deprotection of TBS in the presence of TBDPS

\begin{tabular}{|c|c|c|c|}
\hline Reagents and conditions & 21 & 22 & diol $^{a}$ \\
\hline $\begin{array}{l}\mathrm{LiCl}(50 \mathrm{eq}), \mathrm{H}_{2} \mathrm{O}, \mathrm{DMF}, 90^{\circ} \mathrm{C}, 2 \mathrm{~d} \\
\text { then } 130^{\circ} \mathrm{C}, 4 \mathrm{~d}\end{array}$ & $9 \%$ & $55 \%$ & $\lambda T^{t}$ \\
\hline $\begin{array}{l}\mathrm{CeCl}_{3}(1.5 \mathrm{eq}), \mathrm{Nal}(1.0 \mathrm{eq} .), \mathrm{CH}_{3} \mathrm{CN}, \mathrm{rt}, 3 \mathrm{~d} \\
\text { then } 50^{\circ} \mathrm{C}, 7 \mathrm{~h}\end{array}$ & $25 \%$ & $18 \%$ & $50 \%$ \\
\hline PPTS (0.9 eq. ), EtOH, rt, $3 \mathrm{~d}$ & $60 \%$ & $29 \%$ & $8 \%$ \\
\hline PPTS $(0.9 \mathrm{eq}), p-\mathrm{TsOH}(0.3 \mathrm{eq}), \mathrm{rt}, 7 \mathrm{~h}$ & $46 \%$ & $43 \%$ & $M$ \\
\hline
\end{tabular}

Compound in which both TBS and TBDPS groups of 21 are cleaved. "Not isolated.
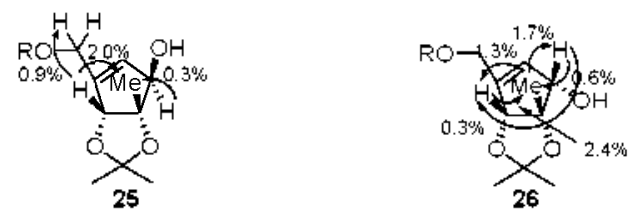

Figure 2. 'H NOE experiment data of 5-methy lcyclopentenols, 25 and 26.

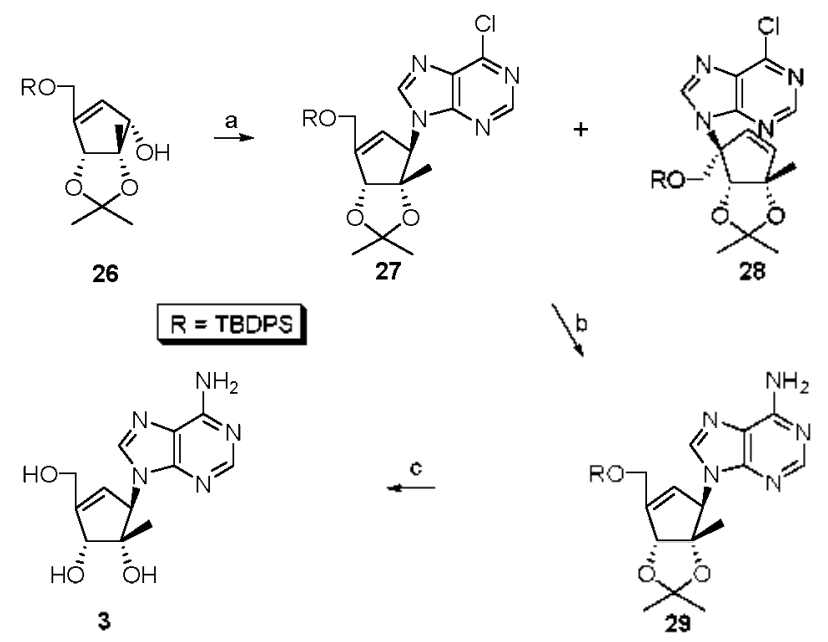

Scheme 5. Reagents and conditions: (a) 6-chloropurine, $\mathrm{PPh}_{3}, \mathrm{DEAD}$, $\mathrm{THF}, \mathrm{rt}, \mathrm{l}, 42 \%$ for $27,3 \%$ for 28 (b) methanolic ammonia, $\mathrm{MeOH}$, $80^{\circ} \mathrm{C}, 7 \mathrm{~h}, 84 \%$, (c) $4 \mathrm{NHCl}, \mathrm{MeOH}$, rt $, 6 \mathrm{~h}, 86 \%$

ment with PPTS (pyridinium $p$-toluenesulfonate) ${ }^{23}$ the reaction proceeded too slowly and in addition. when the reaction time was long. a ratio of the desired product 22 and the diol compound decreased. The best result was obtained by treatment with PPTS and $\mathrm{TsOH}$ in $\mathrm{EtOH}$. In contrast to the treatment with PPTS only. addition of TsOH with PPTS accelated the reaction rate and the yield was also acceptable ( $45 \%$. recovered yield: $83 \%$ ). Maybe. low chemoselectivity between TBDPS and TBS in the various removal reactions results from an existence of TBDPS at the allylic position.

Swern oxidation of 22 followed by a Grignard reaction of the resulting aldehyde 23 gave dienes $24 \alpha$ and $2+\beta(2+\alpha) 2+\beta=$ $2.3: 1)$ as an easily separable diastereomeric mixture on a column chromatography. Each diastereomer $\mathbf{2 4} \beta$ and $\mathbf{2 4} \alpha$ was subjected to a RCM reaction with a second Grubbs catalyst to afford $\beta$-cyclopentenol 25 and its $\alpha$-isomer 26 , respectively. Conversion of 25 into 26 was examined. After an oxidation of 25. a diastereo- and regioselective reduction of 14 was accomplished with a Luche reduction ${ }^{24}$ using $\mathrm{NaBH}_{4}$ in the presence of $\mathrm{CeCl}_{3}$ to give 26 , along with $25(26 / 25=4 / 1)$. A Dibal-H reduction was chosen as an alternative method to improve the diastereoselectivity. Surprisingly. reduction of $1+$ with Dibal-H showed a superior diastereoselectivity to produce 26 in $93 \%$ yield with a trace of 25 . The stereochemistry of cyclopentenols $\mathbf{2 5}$ and $\mathbf{2 6}$ was confirmed by NOE experiments (Figure 2).

Upon the coupling reaction of 26 with 6 -chloropurine under Mitsunobu conditions, ${ }^{25} 27$ was generated as the desired product in $42 \%$ yield, along with a migrated nucleoside $28(3 \%)$. formed via an $\dot{\mathrm{S}}_{\mathrm{N}} 2^{\prime}$ mechanism $(27: \mathbf{2 8}=1+: 1)$ (Scheme 5). $2^{\prime}-\beta-C-$ Metlyy Ineplanocin A (3) was obtained from amination with methanolic ammonia and hydrolysis with $4 \mathrm{~N} \mathrm{HCl}$. Disappointingly. $2^{\prime}-\beta-C$-methylneplanocin $A$ did not show significant activity against $\mathrm{HCV}$ and also recently Merck company published a paper related to the synthesis of the same final compound 3 as a communication form. ${ }^{26}$ The lack of anti-HCV activity might result from a steric hindrance of $2^{\prime}-\beta-C$-methyl substituent 
when $2^{\prime}-\beta-C$-methylneplanocin A and/or its phosphates interacted with kinases and/or polymerases. Biological evaluation against other viruses is currently underway. and will be reported in due course.

\section{Conclusions}

We have synthesized $2^{\prime}-\beta-C$-methylneplanocin $A(3)$ as potential anti-HCV agent starting from $2-\beta-C-$-methylribonolactone. obtained from employing the modified Whistler and BeMiller's method. PDC oxidation of 11 in DMF has afforded cyclopentenone 14, but due to the purification problem of the product. the strategy could not be used in the large scale. RCM reaction of dienes $24 \alpha$ and $2+\beta$ gave $\alpha$-cyclopentenol 26 and $\beta$ -cyclopentenol 25 . respectively and $\mathbf{2 5}$ could be converted into 26 by an oxidation and a diastereoselective reduction. It is noteworthy that the reduction of cyclopentenone 14 with Dibal-H gave much better diastereoselectivity than a Luche reduction. Attempts to deprotect TBS group in the presence of TBDPS group were made and the best result was obtained from a use of PPTS and TsOH together. It is also noteworthy that coupling of 26 with 6-chloropurine under Mitsunobu conditions gave 27 via an $\mathrm{S}_{\mathrm{2}} 2$ mechanism and a migrated nucleoside 28 wa an $\mathrm{S}_{\mathrm{N}} 2^{\prime}$ mechanism. $2^{\prime}-\beta-C-$-Methỵlneplanocin $\mathrm{A}$ did not show significant activity against $\mathrm{HCV}$, implying that cellular kinases and/or HCV's poly merases might not accommodate the $2^{\prime}-\beta-C$-methyll substituent.

\section{Experimental}

General. Melting points are uncorrected. ${ }^{1} \mathrm{H}$ and ${ }^{17} \mathrm{C}$ NMR spectra were recorded on Varian Unity INOVA 400 and Varian Unity AS 500 instruments. Chemical shifts are reported with reference to the respective residual solvent or deuteriated peaks ( $\delta_{\mathrm{H}} 3.30$ and $\delta_{0}, 49.0$ for $\mathrm{CD}_{3} \mathrm{OD}, \hat{\mathrm{o}}_{\mathrm{H}} 7.27$ and $\delta_{.} 77.0$ for $\mathrm{CDCl}_{3}$ ). Coupling constants are reported in hertz. The abbreviations used are as follows: $s$ (singlet), $d$ (doublet), $m$ (multiplet). $t$ (triplet). dd (doublet of doublet). br s (broad singlet). All the reactions described below were performed under argon or nitrogen atmosphere and monitored by TLC. All anhydrous solvents were distilled over $\mathrm{CaH}_{2}$ or $\mathrm{Na}$ /benzophenone prior to use. Assignments of ${ }^{l} \mathrm{H}$ NMR data were conducted on the basis of nucleoside mumbering.

Synthesis of D-2- $\beta-C$-methylribono-1,4-lactone: To D-fructose $(100 \mathrm{~g} .555 .1 \mathrm{mmol})$ were added boiling water $(1000 \mathrm{~mL})$ and $\mathrm{Ca}(\mathrm{OH})_{2}(10 \mathrm{~g} .135 .0 \mathrm{mmol})$ successively. The reaction mixture was stirred at room temperature for $5 \mathrm{~h}$ and at $50^{\circ} \mathrm{C}$ for $3 \mathrm{~d}$. Additional $\mathrm{Ca}(\mathrm{OH})_{2}(40 \mathrm{~g} .540 .0 \mathrm{mmol})$ was added and the reaction mixture was stirred at $50^{\circ} \mathrm{C}$ for additional $3 \mathrm{~d}$. After cooling. the reaction mixture was filtered and to the filtrate was added oxalic acid dilydrate ( $38 \mathrm{~g} .301 .+\mathrm{mmol}$ ). After being stirred vigorously for $10 \mathrm{~min}$. the mixture was filtered through a pad of Celite. The filtrate was filtered again through Amberlite IR$120 \mathrm{H}$ ion-exchange resin under a gravity. After evaporation, the residue was purified by silica gel column chromatography. In the first silica gel column chromatography a co-solvent of methylene chloride and methanol (2:1) was used as the eluent and in the second one. ethyl acetate was used as the eluent to give
$D-2-\beta-C$-nethy lribonolactone $(10-15 \%)$ as a white solid. All spectral data were identical to those of the authentic sample.

(3aR,6R,6aR)-Dihy dro-6-(hy dmxymethyl)-2,2,3a-trimethylfuro $[3,4-d][1,3]$ dioxol- $-(3 a H)$-one $(15)$ : $2-\beta-C-$-Methylribonolactone ( $1.03 \mathrm{~g} .6 .35 \mathrm{mmol}$ ) was converted to 15 ( $1.18 \mathrm{~g}$. $91 \%$ ) as a colorless oil according the reported procedure $\left.[\alpha]_{[}^{5}\right)-34.4\left(c 1.17 . \mathrm{CHCl}_{2}\right):{ }^{1} \mathrm{H}$ NMR $\left(400 \mathrm{MHz}, \mathrm{CDCl}_{3}\right) \delta$ $4.70-4.50$ (m. $2 \mathrm{H}$ ). 3.97 (dd, $1 \mathrm{H} . J=3.2 .12 .4 \mathrm{~Hz}$ ), 3.80 (dd, $1 \mathrm{H}, J=2.8,12.4 \mathrm{~Hz}) .2 .61($ br s, $1 \mathrm{H}), 1.63(\mathrm{~s}, 3 \mathrm{H})$. $1.41(\mathrm{~s}, 3 \mathrm{H}) .1 .40(\mathrm{~s} .3 \mathrm{H}):{ }^{13} \mathrm{C} \mathrm{NMR}\left(100 \mathrm{MHz}, \mathrm{CDCl}_{3}\right) \delta$ $177.1,113.1,83.7 .83 .1 .82 .8 .62 .3 .27 .0$. 26.9. 20.0; LRMS(FAB+) $m / z 203(\mathrm{M}+\mathrm{H})^{+}$.

$(3 \mathrm{a} R, 6 R, 6 \mathrm{a} R)-6$-(tert-Butyll-diphenyl-silanyloxymethy))dihydio-2,2,3a-trimethylfuıo $[3,4-d][1,3]$ dioxol-4(3aH)-one (16): To a solution of 15 (1.18 g. $5.84 \mathrm{mmol})$ and imidazole (792 $\mathrm{mg}, 11.63 \mathrm{mmol}$ ) in anhydrous metlyy lene chloride (15 $\mathrm{mL}$ ) was added tert-buț̣ldiphenylsilyl chloride ( $1.51 \mathrm{~mL}$. $5.90 \mathrm{mmol}$ ) dropwise at $0^{\circ} \mathrm{C}$. After being stirred at room temperature for $2 \mathrm{~h}$. the reaction mixture was extracted with methy lene cliloride. The organic layer was dried over anhydrous $\mathrm{MgSO}_{4}$. filtered, and evaporated under reduced pressure. The residue was purified by silica gel column chromatography using hexanes and etlyl acetate (12:1) as the eluent to give silyl ether $16(2.51 \mathrm{~g} .98 \%)$ as a colorless oil: $[\alpha]_{[}^{2}+2.1(c$ 1.31. $\left.\mathrm{CHCl}_{3}\right)$. ${ }^{1} \mathrm{H}$ NMR $\left(500 \mathrm{MHz}, \mathrm{CDCl}_{3}\right) \delta 7.66-7.40(\mathrm{~m}$, $10 \mathrm{H}), 4.53$ (s. I H), 4.51 (t. l H. $J=3.5 \mathrm{~Hz}), 3.83$ (d. $2 \mathrm{H}$. $J=3.5 \mathrm{~Hz}), 1.59(\mathrm{~s} .3 \mathrm{H}), 1.45(\mathrm{~s} .3 \mathrm{H}), 1.44(\mathrm{~s} .3 \mathrm{H}), 1.07(\mathrm{~s}$. $9 \mathrm{H}):{ }^{1-2} \mathrm{C}$ NMR $\left(100 \mathrm{MHz}, \mathrm{CDCl}_{3}\right) \delta 176.3,135.8 .135 .7$, $132.6,132.3,130.3,128.2,113.3,83.1,82.6,82.5,63.8$, $27.2,27.1 .27 .0 .20 .6 .19 .4 ;$ LRMS(FAB $+m / z+63(\mathrm{M}+\mathrm{Na})^{+}$ $\mathrm{HRMS}(\mathrm{FAB}+) m / z \mathrm{C}_{25} \mathrm{H}_{32} \mathrm{O}_{5} \mathrm{SiNa}(\mathrm{M}+\mathrm{Na})^{-}$calcd 463.1917 . obsd 463.1924

(3aR,6R,6aR)-6-(tert-Butyl-diphenyl-silanyloxymethyl)tetrahydio-2,2,3a-timethylfuro $[3,4-d][1,3]$ dioxol-4-ol (17): To a stirred solution of $16(2.7+\mathrm{g} .6 .22 \mathrm{~nm}$ ol $)$ in anlydrous methy lene chloride $(25 \mathrm{~mL}$ ) was added diisobuty lalumimum hydride (Dibal-H, 6.6 mL. $6.6 \mathrm{mmol}$. 1.0 M solution in hexanes) at $-78^{\circ} \mathrm{C}$. and the reaction mixture was stirred for $30 \mathrm{~min}$ at the same temperature. $\mathrm{MeOH}(6.6 \mathrm{~mL})$, hexanes $(13.2 \mathrm{~mL})$ and ethyl acetate $(13.2 \mathrm{~mL})$ were added successively and the resulting mixture was stirred overnight. allowing it to reach room temperature. The generated gel was filtered off through a pad of Celite and the filtrate was concentrated under reduced pressure. The residue was purified by silica gel column cluromatography using hexanes and ethyl acetate $(7: 1)$ as the eluent to give lactol $17(2.70 \mathrm{~g} .98 \%)$ as a colorless oil: $[\alpha]_{\mathrm{L}}^{25} 7.0$ (c 1.25, $\left.\mathrm{CHCl}_{3}\right) ;{ }^{1} \mathrm{H}$ NMR $\left(400 \mathrm{MHz}, \mathrm{CDCl}_{3}\right) \delta$ $7.68-7.36(\mathrm{~m}, 20 \mathrm{H}), 5.19$ (d. $1 \mathrm{H}, J=10.0 \mathrm{~Hz}) .5 .09$ (d. $1 \mathrm{H}$. $J=10.4 \mathrm{~Hz}) .4 .51(\mathrm{~d}, 1 \mathrm{H}, J=2.0 \mathrm{~Hz}), 4.45(\mathrm{~d} .1 \mathrm{H} . J=1.2 \mathrm{~Hz})$, $4.2 \mathrm{l}(\mathrm{d}, 1 \mathrm{H} . J=10.0 \mathrm{~Hz}) .4 .19-4.17(\mathrm{~m}, 1 \mathrm{H}) .4 .13-4.11(\mathrm{~m}$. l H). 3.80 (d. $1 \mathrm{H}, J=10.8 \mathrm{~Hz}$ ). $3.77-3.63(\mathrm{~m},+\mathrm{H}), 1.53$ (s. $3 \mathrm{H}) .1 .48(\mathrm{~s}, 3 \mathrm{H}), 1.46(\mathrm{s.} 3 \mathrm{H}) .1 .45(\mathrm{~s}, 3 \mathrm{H}), 1.4+(\mathrm{s.} 3 \mathrm{H})$. 1.43 (s. $3 \mathrm{H}), 1.07$ (s. $9 \mathrm{H}), 1.05$ (s. $9 \mathrm{H}):{ }^{1 \mathrm{j}} \mathrm{C} \mathrm{NMR}(100 \mathrm{MHz}$, $\left.\mathrm{CDCl}_{3}\right) \delta 135.9 .135 .9,135.8 .133 .0,132.8,131.9 .131 .7$. $130.5,130.4 .130 .1,130.1,128.3,128.1 .113 .8,112.9 .104 .6$. $102.3,92.7,88.2 .87 .4 .87 .1 .86 .9 .82 .5 .65 .6 .65 .2,28.9$, $28.1 .27 .6 .27 .5 .27 .1 .22 .2 .20 .5 .19 .4: \mathrm{LRMS}(\mathrm{FAB}+) \mathrm{m} / \mathrm{z}$ $465(\mathrm{M}+\mathrm{Na})^{+}:$HRMS(FAB+) $m / z \mathrm{C}_{25} \mathrm{H}_{34} \mathrm{O}_{5} \mathrm{SiNa}(\mathrm{M}+$ 
$\mathrm{Na)^{- }}$ calcd 465.2073 , obsd 465.2060 .

(R)-2-(tert-Butyl-diphenyl-silanyloxy)-1- $((+R, 5 S)-5-$ (hydroxymethyl)-2,2,5-trimethyl-1,3-dioxolan-4-yl)ethanol (18): To a solution of $17(2.46 \mathrm{~g} .5 .56 \mathrm{mmol})$ in $\mathrm{MeOH}(24.6$ $\mathrm{mL}$ ) were added sodium borohydride ( $210 \mathrm{mg} .5 .56 \mathrm{mmol}$ ) and the mixture was stirred under reflux for $30 \mathrm{~min}$. After cooling to room temperature. the reaction mixture was evaporated under reduced pressure until the volumn of solution became $5 \mathrm{~mL}$ and extracted with ethyl acetate. The organic layer was dried over anlyydrous $\mathrm{MgSO}_{4}$. filtered. and evaporated $i n$ vacuo. The residue was purified by silica gel column chromatography using hexanes and ethyl acetate $(2.5: 1)$ as the eluent to give diol $18(2.23 \mathrm{~g} .94 \%)$ as a colorless oil: $\left.[\alpha]_{\mathrm{L}}^{25}-11.0(c) 1.72 . \mathrm{CHCl}_{3}\right):{ }^{1} \mathrm{H}$ NMR $\left(400 \mathrm{MHz}, \mathrm{CDCl}_{3}\right) \delta$ $7.67-7.36(\mathrm{~m} .10 \mathrm{H}) .3 .91-3.83(\mathrm{~m} .3 \mathrm{H}) .3 .76(\mathrm{dd} .1 \mathrm{H} . J=$ $6.0,11.2 \mathrm{~Hz}), 3.69(\mathrm{~d}, 1 \mathrm{H}, J=11.2 \mathrm{~Hz}), 3.52(\mathrm{~d}, 1 \mathrm{H} . J=$ $11.2 \mathrm{~Hz}) .2 .71$ (s. $2 \mathrm{H}), 1.43$ (s. $3 \mathrm{H}), 1.33(\mathrm{~s} .6 \mathrm{H}) .1 .07$ (s. $9 \mathrm{H}) ;{ }^{13} \mathrm{C}$ NMR $\left(100 \mathrm{MHz} . \mathrm{CDCl}_{3}\right) \delta 135.8,135.7 .133 .1$. 133.0, 130.2. 130.1. 128.1, 128.0. 108.1, 83.0.81.4.70.2. $65.8,65.5,28.6,27.1,26.8,23.8,19.5:$ LRMS(FAB +$) m / z$ $467(\mathrm{M}+\mathrm{Na})^{-} ; \mathrm{HRMS}(\mathrm{FAB}+)^{2} / z \mathrm{C}_{35} \mathrm{H}_{36} \mathrm{O} ; \mathrm{SiNa}(\mathrm{M}+$ $\mathrm{Na})^{-}$calcd 467.2230 . obsd 467.2221

$(R)$-(tert-Buty]-dipheny]-silanyloxy)-1-((4R,5S)-5-(tertbutyl-dimethyl-silany loxymethyl)-2,2,5-trimethyl-1,3dioxolan-4-yl)ethanol (19): To a solution of $18(2.90 \mathrm{~g} .6 .52$ $\mathrm{mmol}$ ) and imidazole (972 mg. $14.3+\mathrm{mmol}$ ) in anhydrous methỵ lene chloride $(63 \mathrm{~mL}$ ) was added tert-buty ldimethy'sily'l clloride $(1.08 \mathrm{~g}, 7.17 \mathrm{mmol})$ portionw ise at $0{ }^{\circ} \mathrm{C}$. After being stirred at room temperature for $3 \mathrm{~h}$. the reaction mixture was extracted with methylene chloride. The organic layer was dried over anhydrous $\mathrm{MgSO}_{4}$ filtered. and evaporated under reduced pressure. The residue was purified by silica gel column chromatography using hexanes and ethyl acetate $(15: 1)$ as the eluent to give silyl ether 19 (3.64 g. 99\%) as a colorless oil: $[\alpha]_{\mathrm{D}}^{25}-9.1$ (c 1.01. $\left.\mathrm{CHCl}_{3}\right):{ }^{1} \mathrm{H}$ NMR $\left(400 \mathrm{MHz}, \mathrm{CDCl}_{3}\right) \delta$ 7.73-7.34 (m. $10 \mathrm{H}) .3 .94-3.80(\mathrm{~m} .+\mathrm{H}) .3 .74$ (d. I H. $J=$ $10.4 \mathrm{~Hz}$ ), 3.60 (br s, $1 \mathrm{H}) .3 .30$ (d, $1 \mathrm{H}, J=9.6 \mathrm{~Hz}) .1 .41$ (s, $3 \mathrm{H}) .1 .33(\mathrm{~s} .3 \mathrm{H}) .1 .31$ (s. $3 \mathrm{H}), 1.06$ (s. $9 \mathrm{H}) .0 .91$ (s. $9 \mathrm{H}$ ). 0.11 (s. $3 \mathrm{H}), 0.10(\mathrm{~s} .3 \mathrm{H}):{ }^{13} \mathrm{C}$ NMR $\left(100 \mathrm{MHz}, \mathrm{CD}_{3} \mathrm{OD}\right) \delta$ $135.6,135.6,133.6 .133 .5,129.6,129.6 .127 .6 .127 .5,107.5$. $82.3 .81 .1,70.7 .66 .1,66.0 .27 .4 .26 .1 .25 .6,25.2 .22 .9 .18 .9$. $18.0,-6.6 ; \mathrm{LRMS}(\mathrm{FAB}+) m / z 5+3\left(\mathrm{M}-\mathrm{CH}_{3}\right)^{+}$.

2-(tert-Butyl-diphenyl-silanyloxy)-1-((+S,5S)-5-(tertbutyl-dimethyl-silanyloxy methyl)-2,2,5-trimethyl-1,3dioxolan-4-yl)ethanone (20): To a stirred solution of oxalyl chloride $(0.97 \mathrm{~mL}, 11.12 \mathrm{mmol})$ in dry methylene chloride ( 25 $\mathrm{mL}$ ) was added dimethyl sulfoxide ( $1.71 \mathrm{~mL}, 24.10 \mathrm{mmol}$ ) at $-78^{\circ} \mathrm{C}$. and the mixture was stirred at $-78^{\circ} \mathrm{C}$ for $30 \mathrm{~min}$. To this mixture was added a solution of $19(3.64 \mathrm{~g} .6 .51 \mathrm{mmol})$ in methylene chloride $(20 \mathrm{~mL})$, and the reaction mixture was stirred at $-78^{\circ} \mathrm{C}$ for $1 \mathrm{~h}$. After the addition of triethylamine $(6.30 \mathrm{~mL}$. $45.20 \mathrm{mmol}$ ). the mixture was gradually warmed to room temperature. The reaction mixture was quenched with water and then extracted with methy lene chloride. The organic layer was dried over anhydrous $\mathrm{MgSO}_{4}$ filtered, and evaporated under reduced pressure. The residue was purified by silica gel column chromatography using hexanes and ethyl acetate $(18: 1)$ as the eluent to give ketone $\mathbf{2 0}(3.62 \mathrm{~g} .99 \%)$ as a colorless oil:
$[\alpha]_{\mathrm{L}}^{25}-17.9\left(c 2.04 . \mathrm{CHCl}_{3}\right) ;{ }^{1} \mathrm{H}$ NMR $\left(500 \mathrm{MHz}, \mathrm{CDCl}_{3}\right) \delta$ $7.71-7.36(\mathrm{~m}, 10 \mathrm{H}) .4 .77(\mathrm{~d} .1 \mathrm{H}, J=18.0 \mathrm{~Hz}) .4 .41(\mathrm{~d} .1 \mathrm{H}$. $J=18.0 \mathrm{~Hz}$ ). 4.33 (s. $1 \mathrm{H}$ ). $3.52(\mathrm{~d} .1 \mathrm{H} . J=10.0 \mathrm{~Hz}) .3 .44$ (d. $1 \mathrm{H}, J=10.0 \mathrm{~Hz}) \cdot 1.46(\mathrm{~s} .3 \mathrm{H}) \cdot 1.42(\mathrm{~s} .3 \mathrm{H}), 1.32(\mathrm{~s} .3 \mathrm{H}$ ), 1.10 (s. $9 \mathrm{H}$ ). 0.88 (s. $9 \mathrm{H}), 0.05$ (s. $3 \mathrm{H}), 0.04$ (s. $3 \mathrm{H}$ ): ${ }^{13} \mathrm{C}$ $\mathrm{NMR}\left(100 \mathrm{MHz} . \mathrm{CDCl}_{3}\right) \delta 204.6,135.9,135.8 .133 .5 .133 .1$, $130.0,123.0,128.0,127.9 .109 .2 .84 .7,84.6,68.7 .66 .2 .27 .8$. $26.9 .26 .7 .26 .2,24.0,19.5,18.7,-5.3,-5.6 ;$ LRMS(FAB +$)$ $m / z 579(\mathrm{M}+\mathrm{Na})^{-} ; \mathrm{HRMS}(\mathrm{FAB}+) m / z \mathrm{C}_{31} \mathrm{H}_{48} \mathrm{O}_{5} \mathrm{Si}_{2} \mathrm{Na}(\mathrm{M}+$ $\mathrm{Na})^{-}$calcd 579.2938. obsd 579.2951 .

$(+S, 5 R)-4-($ tert - Butyl-dimethyl-silanyloxymethyl)-5(3-tert-butyl-diphenyl-silanyloxyprop-1-en-2-yl)-2,2,4trimethyl-1,3-dioxolane (21): To a stirred suspension of methy'ltripheny'lphosphonium bromide $(4.91 \mathrm{~g} .13 .74 \mathrm{mmol})$ in anhydrous tetrahydrofuran $(60 \mathrm{~mL})$ was added potassium tertbutoxide $(1.68 \mathrm{~g} .13 .75 \mathrm{mmol})$ at $0^{\circ} \mathrm{C}$, and the mixture was stirred at room temperature for $l \mathrm{~h}$ to give a yellow suspension. A solution of $20(3.83 \mathrm{~g}, 6.88 \mathrm{mmol})$ in aultydrous THF $(35 \mathrm{~mL})$ was added dropwise at $0{ }^{\circ} \mathrm{C}$. and the reaction mixture was allowed to reach room temperature. After being stirred for an additional $1.5 \mathrm{~h}$. the reaction mixture was treated with saturated aqueous $\mathrm{NH}_{4} \mathrm{Cl}$ solution $(20 \mathrm{~mL})$. The aqueous layer was extracted with diethyl ether and the organic layer was dried over anhydrous $\mathrm{MgSO}_{4}$. filtered. and evaporated in vacuo. The residue was purified by silica gel column chromatography using hexanes and ethyl acetate (30:1) as the eluent to give olefin $21(3.55 \mathrm{~g} .92 \%)$ as a colorless oil: $[\alpha]_{\mathrm{D}}^{35}$ -8.6 (c 2.21, $\mathrm{CHCl}_{3}$ ): ${ }^{1} \mathrm{H}$ NMR ( $\left.400 \mathrm{MHz} . \mathrm{CDCl}_{3}\right) \delta 7.68-$ 7.35 (m. $10 \mathrm{H}$ ). 5.37 (s. I H), 5.22 (s. I H), 4.52 (s. I H). $4.24($ d. $1 \mathrm{H}, J=12.8 \mathrm{~Hz}), 4.18($ d. $1 \mathrm{H}, J=13.2 \mathrm{~Hz}), 3.47$ (d. $1 \mathrm{H} . J=9.6 \mathrm{~Hz}$ ). 3.17 (d. $1 \mathrm{H} . J=9.6 \mathrm{~Hz}), 1.43$ (s. $3 \mathrm{H}$ ). $1.39(\mathrm{~s}, 3 \mathrm{H}) .1 .32(\mathrm{~s} .3 \mathrm{H}), 1.05(\mathrm{~s} .9 \mathrm{H}) .0 .79(\mathrm{~s}, 9 \mathrm{H}) .0 .04$ (s. $3 \mathrm{H}), 0.07$ (s. $3 \mathrm{H}):{ }^{12} \mathrm{C} \mathrm{NMR}\left(100 \mathrm{MHz}, \mathrm{CDCl}_{3}\right) \delta 1+2.8$, 135.8. 135.7, 133.7. 133.7. 129.9. 129.9, 127.9. 127.9. 110.8. $106.9 .82 .2,81.6 .65 .8 .65 .6 .28 .6 .27 .0 .26 .6 .26 .0,22.3$, 19.5, 18.5, -5.4. $-5.5:$ LRMS $(\mathrm{FAB}+) \mathrm{m} / 2577(\mathrm{M}+\mathrm{Na})^{+}:$HRMS $(\mathrm{FAB}+) m / z \mathrm{C}_{32} \mathrm{H}_{3} \mathrm{O}_{4} \mathrm{Si}_{2} \mathrm{Na}(\mathrm{M}+\mathrm{Na})^{+}$calcd 577.3145 . obsd 577.3132

$((+S, 5 R)-5$-(3-tert-Butyl-diphenyl-silanyloxyprop-1-en2-yl)-2,2,-trimethyl-1,3-dioxolan-4-yl)methanol (22): To a stirred solution of 21 (1.94 g. $3.53 \mathrm{mmol})$ in EtOH $(60 \mathrm{~mL})$ was added pyridinium $p$-toluene sulfonate ( $800 \mathrm{mg}, 3.20 \mathrm{nunol}$ ) and $p$-toluene sulfonic acid (200 $\mathrm{mg}$. $1.04 \mathrm{mmol}$ ) at room temperature. After being stirred at the same temperature for $7 \mathrm{~h}$, the reaction mixture was extracted with ethyl acetate. The organic layer was dried over anlyydrous $\mathrm{MgSO}_{4}$. filtered. and evaporated under reduced pressure. The residue was purified by silica gel column chromatography using hexanes and ethyl acetate (6:1) as the eluent to give alcohol 22 (697 $\mathrm{mg} .45 \%$, recovered y ield: $83 \%$ ) as a colorless oil with staring material 21 (898 mg): $[\alpha]_{\mathrm{L}}^{35}-1+.2\left(c 1.10, \mathrm{CHCl}_{3}\right):{ }^{3} \mathrm{H}$ NMR (400 $\left.\mathrm{MHz} . \mathrm{CDCl}_{s}\right) \delta 7.68-7.36(\mathrm{~m}, 10 \mathrm{H}), 5.43(\mathrm{~s}, 1 \mathrm{H}), 5.41(\mathrm{~s}$, $1 \mathrm{H}) .4 .40$ (s. I H). 4.17 (d. 1 H. $J=13.6 \mathrm{~Hz}$ ). 4.10 (d. I H. $J=$ $13.6 \mathrm{~Hz}$ ). 3.33 (dd. $1 \mathrm{H} . J=4.8,11.2 \mathrm{~Hz}$ ). 3.21 (dd. $1 \mathrm{H} . J=$ $8.4,11.2 \mathrm{~Hz}), 1.86-1.82(\mathrm{~m}, \mathrm{~L} \mathrm{H}), 1.46(\mathrm{~s} .3 \mathrm{H}), 1.38(\mathrm{~s} .3 \mathrm{H})$. $1.31(\mathrm{~s}, 3 \mathrm{H}) \cdot 1.05(\mathrm{~s} .9 \mathrm{H}):{ }^{13} \mathrm{C} \mathrm{NMR}\left(100 \mathrm{MHz}, \mathrm{CDCl}_{3}\right) \delta$ $1+2.0 .135 .7$. 133.2. 133.2.130.1. 128.0, 112.6. 107.6.82.1. $82.0 .65 .5 .64 .8 .28 .5 .27 .0 .26 .7 .22 .0,19.4:$ LRMS (FAB+) 
$m / z+63(\mathrm{M}+\mathrm{Na})^{-} ; \mathrm{HRMS}(\mathrm{FAB}+) m / z \mathrm{C}_{26} \mathrm{H}_{36} \mathrm{O}_{4} \mathrm{SiNa}(\mathrm{M}+$ $\mathrm{Na})^{-}$calcd 463.2281 , obsd 463.2267 .

(4R,5R)-5-(3-tert-Butyl-diphenyl-silanyloxyprop-1-en-2yl)-2,2,4-trimethyl-1,3-dioxolane-4-carbaldehyde (23): Compound 22 (808 $\mathrm{mg} .1 .83 \mathrm{mmol}$ ) was converted to 23 (780 $\mathrm{mg}$. $97 \%$ ) as a colorless oil in a similar procedure used for the synthesis of 20: $[\alpha]_{\mathrm{D}}^{20}-12.9$ (c 2.16. $\left.\mathrm{CHCl}_{3}\right):{ }^{\mathrm{l}} \mathrm{H}$ NMR (400 $\left.\mathrm{MHz} \mathrm{CDCl}_{3}\right) \delta 9.36(\mathrm{~s} .1 \mathrm{H}) .7 .66-7.36(\mathrm{~m}, 10 \mathrm{H}) .5 .35-5.34$ $(\mathrm{m}, 2 \mathrm{H}), 4.60$ (s. $1 \mathrm{H}) .4 .13(\mathrm{~d}, 1 \mathrm{H} . J=13.6 \mathrm{~Hz}) .4 .07$ (d, I H. $J=14.4 \mathrm{~Hz}$ ) 1.47 (s. $3 \mathrm{H}$ ). 1.35 (s. $3 \mathrm{H}), 1.24$ (s. $3 \mathrm{H}$ ), $1.04(5.9 \mathrm{H}):{ }^{13} \mathrm{C} \mathrm{NMR}\left(100 \mathrm{MHz}, \mathrm{CDCl}_{3}\right) \delta 200.5 .140 .5$, $135.7,135.7,133.3 .133 .2,130.1,130.0,128.0,128.0,113.1$. $110.2,85.3 .83 .1,64.6 .28 .2,27.0,26.5 .19 .5,16.5$; LRMS $(\mathrm{FAB}+) m / z+39(\mathrm{M}+\mathrm{H})^{+}: \mathrm{HRMS}(\mathrm{FAB}+) m / z \mathrm{C}_{26} \mathrm{H}_{35} \mathrm{O}_{4} \mathrm{Si}$ $(\mathrm{M}+\mathrm{H})^{-}$calcd +39.2305 . obsd 439.2312

1-((4S,5R)-5-(1-tert-Butyl-diphenyl-silanyloxyvinyl)2,2,+-trimethyl-1,3-dioxolan-4-yl)pmp-2-en-1-ol (24): To a stirred solution of $23(780 \mathrm{mg}, 1.78 \mathrm{mmol})$ in tetrahydrofuran (20 $\mathrm{mL}$ ) was added viny lmagnesium bromide ( $\mathrm{I}$ M solution in tetrahydrofuran. $3.56 \mathrm{~mL}, 3.56 \mathrm{mmol}$ ) at $-78^{\circ} \mathrm{C}$, and the reaction mixture was stirred at $-78^{\circ} \mathrm{C}$ for $1 \mathrm{~h}$. After being quenched with saturated ammonium chloride solution. the mixture was allowed to warm to room temperature. extracted with diethyl ether. dried over anhydrous magnesium sulfate. filtered, and concentrated to dryness. The residue was purified by silica gel column chromatography using hexanes and ethyl acetate (15: 1 ) as the eluent to give diene $24 a(530 \mathrm{mg}$. $64 \%$ ) and $24 \beta(230 \mathrm{mg}, 28 \%$ ) as a colorless oil: compound $24 \alpha$ : $\left.[\alpha]_{[j}^{25}-44.9(c) 1.03, \mathrm{CHCl}_{3}\right):{ }^{1} \mathrm{H}$ NMR $\left(400 \mathrm{MHz}, \mathrm{CDCl}_{3}\right) \delta$ $7.70-7.37(\mathrm{~m}, 10 \mathrm{H}), 6.11-6.03(\mathrm{~m}, 1 \mathrm{H}) .5 .59(\mathrm{~s}, 1 \mathrm{H}) .5 .48$ (s. $1 \mathrm{H}) .5 .35$ (td. $1 \mathrm{H} . J=1.6 .17 .2 \mathrm{~Hz}) .5 .24$ (td. I H. $J=$ $1.6,10.8 \mathrm{~Hz}) .4 .34$ (s. $1 \mathrm{H}$ ) $4.25(\mathrm{~d}, 1 \mathrm{H}, J=13.2 \mathrm{~Hz}) .4 .18$ (d. 1 H. $J=13.2 \mathrm{~Hz}$ ). $4.25-4.23$ (m, l H). 2.21 (d, l H. $J=$ $3.6 \mathrm{~Hz}) .1 .48$ (s. $3 \mathrm{H}) .1 .36$ (s. $3 \mathrm{H}) .1 .24$ (s. $3 \mathrm{H}) .1 .06(\mathrm{~s} .9 \mathrm{H})$ : ${ }^{13} \mathrm{C} \mathrm{NMR}\left(100 \mathrm{MHz}, \mathrm{CDCl}_{3}\right) \delta$ 143.8. 136.7, 135.8. 135.8, 133.1. 133.1. 130.1. 128.0. 128.0. 116.2, 112.8 107.4.84.2. 82.9 .71 .5 .65 .1 .28 .5 .27 .0 .26 .6 .19 .4 .18 .6 . LRMS (FAB+) $m / z+67(\mathrm{M}+\mathrm{H})^{-}:$HRMS (FAB+) $m / z \mathrm{C}_{2} \mathrm{H}_{38} \mathrm{O}_{4} \mathrm{SiNa}(\mathrm{M}+$ $\mathrm{Na})^{+}$calcd 489.2437 . obsd 489.2440 : compound $24 \beta$ : $[\alpha]_{\mathrm{D}}^{23}$ $+4.0\left(c 0.86, \mathrm{CHCl}_{3}\right) ;{ }^{1} \mathrm{H}$ NMR $\left(400 \mathrm{MHz}, \mathrm{CDCl}_{3}\right)$ o $7.67-$ $7.36(\mathrm{~m} .10 \mathrm{H}) .5 .71-5.62(\mathrm{~m} .1 \mathrm{H}) .5 .48(\mathrm{~s} .1 \mathrm{H}) .5 .46(\mathrm{~s} .1 \mathrm{H})$. 5.25 (d. $1 \mathrm{H}, J=17.2 \mathrm{~Hz}), 5.10(\mathrm{~d}, 1 \mathrm{H} . J=10.4 \mathrm{~Hz}) .4 .44$ (s. $1 \mathrm{H}), 4.17$ (d. $1 \mathrm{H}, J=1+.4 \mathrm{~Hz}), 4.11$ (d. $1 \mathrm{H}, J=14.4 \mathrm{~Hz}$ ), 3.98 (d. $1 \mathrm{H}, J=6.4 \mathrm{~Hz}$ ). 2.67 (s, $1 \mathrm{H}$ ). 1.53 (s. $3 \mathrm{H}$ ), 1.39 (s, $3 \mathrm{H}) .1 .15(\mathrm{~s}, 3 \mathrm{H}) \cdot 1.06(5,9 \mathrm{H}):{ }^{13} \mathrm{C} \mathrm{NMR}(100 \mathrm{MHz}, \mathrm{CDCl})$ ô $142.0,135.7,135.7,135.6 .133 .4 .133 .3,130.1,128.0,128.0$. 118.0. 112.5. 107.6,83.8, 82.4, 73.5.64.8. 28.0. 27.0. 26.5, 20.9. 19.5: LRMS (FAB+) $m / z 489(\mathrm{M}+\mathrm{Na})^{-}:$HRMS (FAB+) $m / z \mathrm{C}_{23} \mathrm{H}_{3} \mathrm{O}_{4} \mathrm{Si}(\mathrm{M}+\mathrm{H})^{+}$calcd 467.2618, obsd 467.2612 .

(3aS,+R,6aR)-6-(tert-Butyl-diphenyl-silanyloxymethyl)4,6a-dihy dm-2,2,3a-trimethy l-3a $H$-cyclopenta $[d][1,3]$ dioxol-4-0l (25): To a stirned solution of $2+\beta$ (230 $\mathrm{mg}$. 0.49 mmol) in anhydrous methylene chloride ( $8 \mathrm{~mL}$ ) was added Grubbs catalyst 2 nd generation ( $25 \mathrm{mg} .0 .03 \mathrm{mmol}$ ) at $0^{\circ} \mathrm{C}$, and the reaction mixture was stirred for $7 \mathrm{~h}$ at room temperature. After the volatiles were removed, the resulting residue was purified by column chromatography using hexanes and ethyl acetate $(5: 1)$ as the eluent to give $\beta$-cyclopentenol 25 (190 mg.
$88 \%$ ) as a colorless oil: $[\alpha]_{\mathrm{D}}^{25}-24.6\left(c 0.99 . \mathrm{CHCl}_{3}\right) ;{ }^{1} \mathrm{H} \mathrm{NMR}$ $\left(500 \mathrm{MHz}, \mathrm{CDCl}_{5}\right) \delta 7.70-7.35(\mathrm{~m}, 10 \mathrm{H}), 5.85(\mathrm{~d}, 1 \mathrm{H}, J=$ $2.0 \mathrm{~Hz}$ ) 4.67 (s. I H) 4.60 (d. I H. $J=7.5 \mathrm{~Hz}), 4.36$ (d. I H. $J=16.0 \mathrm{~Hz}), 4.31(\mathrm{~d} .1 \mathrm{H}, J=16.0 \mathrm{~Hz}) .1 .57(\mathrm{~d} .1 \mathrm{H}, J=7.0 \mathrm{~Hz})$. 1.42 (s. $3 \mathrm{H}$ ). 1.39 (s. $3 \mathrm{H}$ ). 1.22 (s.3 H). 1.09 (s. $9 \mathrm{H}):{ }^{13} \mathrm{C} \mathrm{NMR}$ $\left(100 \mathrm{MHz}, \mathrm{CDCl}_{3}\right) \delta 148.5,135.8,135.8,133.5,133.5,130.0$. $128.0,127.9,112.2 .90 .6,89.2,81.6,61.4,29.3,28.8,27.0$. 20.6. 19.5: LRMS (FAB+) $m / z+61(\mathrm{M}+\mathrm{Na})^{-}:$HRMS (FAB+) $m / z \mathrm{C}_{26} \mathrm{H}_{35} \mathrm{O}_{4} \mathrm{Si}(\mathrm{M}+\mathrm{H})^{-}$calcd +39.2305 , obsd 439.2319 .

(3aS,4S,6aR)-6-(tert-Butyl-diphenyl-silanyloxymethyl)4,6a-dihy dro-2,2,3a-trimethyl-3aH-cyclopenta $[d][1,3]$ dioxol-4-ol (26): Method A. To a stirred solution of 24at (400 mg. $0.91 \mathrm{mmol}$ ) in anhydrous methy lene chloride ( $10 \mathrm{~mL}$ ) was added Grubbs cataly st 2 nd generation ( $15 \mathrm{mg} .0 .02 \mathrm{mmol}$ ) at $0^{\circ} \mathrm{C}$. and the reaction mixture was stirred for $6 \mathrm{~h}$ at room temperature. After the volatiles were removed, the resulting residue was purified by column chromatography using hexanes

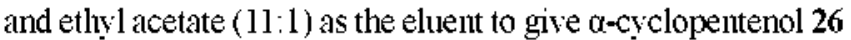
(322 mg. 86\%) as a colorless oil. Method B. To a stirred solution of 14 (14.1 mg, $0.03 \mathrm{mmol}$ ) in anhy drous methylene chloride $(1.5 \mathrm{~mL}$ ) was added diisobutylaluminum lydride (Dibal-H, $0.1 \mathrm{~mL}, 0.1 \mathrm{mmol}, 1.0 \mathrm{M}$ solution in hexanes) at $-78^{\circ} \mathrm{C}$. and the reaction nuxture was stirred for 30 min at the same temperature. $\mathrm{MeOH}(0.1 \mathrm{~mL})$, hexanes $(0.2 \mathrm{~mL})$ and ethyl acetate $(0.2 \mathrm{~mL})$ were added successively and the resulting mixture was stirred overnight. allowing it to reach room temperature. The generated gel was filtered off through a pad of Celite. and the filtrate was concentrated under reduced pressure. The residue was purified by silica gel column chromatography using hexanes and ethyl acetate $(11: 1)$ as the eluent to give $\alpha$-cyclopentenol $26(13 \mathrm{mg} .93 \%)$ as a colorless oil: $[\alpha]_{\overline{5}}^{5}+19.5\left(c 1.00, \mathrm{CHCl}_{2}\right):{ }^{1} \mathrm{H}$ NMR $\left(400 \mathrm{MHz}^{\left.-\mathrm{CDCl}_{3}\right) \delta}\right.$ $7.68-7.32(\mathrm{~m}, 10 \mathrm{H}) .5 .84(\mathrm{~d} .1 \mathrm{H} . J=1.6 \mathrm{~Hz}) .4 .54(\mathrm{~s}, 1 \mathrm{H})$, 4.34 (d, l H, $J=15.6 \mathrm{~Hz}), 4.25$ (d, l H, $J=15.6 \mathrm{~Hz}), 4.20-$ 4.16 (n. $1 \mathrm{H}), 2.73$ (d. $1 \mathrm{H}, J=9.6 \mathrm{~Hz}) .1 .48$ (s. $3 \mathrm{H}), 1.40$ (s. $3 \mathrm{H}) .1 .23$ (s. $3 \mathrm{H}), 1.06$ (s. $9 \mathrm{H}):{ }^{15} \mathrm{C} \mathrm{NMR}(100 \mathrm{MHz}$, $\left.\mathrm{CDCl}_{3}\right) \delta 145.6 .135 .8,135.8$. 133.5, 130.1, 130.0. 127.9. $112.9 .88 .4 .87 .2 .79 .1,61.0,29.6,28.9,27.0,23.7,19.5$ : LRMS (FAB+) $m / z+61(\mathrm{M}+\mathrm{Na})^{-}$: HRMS (FAB+) $m / z$ $\mathrm{C}_{26} \mathrm{H}_{35} \mathrm{O}_{4} \mathrm{Si}(\mathrm{M}+\mathrm{H})^{+}$calcd +39.2305 . obsd +39.2312 .

(3aR,6aR)-6-((tert-Butyl-diphenyl-silanylox y methyl)2,2,3a-trimethy]-3a $H$-cyclopenta $[d][1,3]$ dioxol- $+(6 \mathrm{a} H)$-one (14): To a stirred solution of oxalyl chloride $(0.06 \mathrm{~mL} .0 .69$ nunol) in dry methylene chloride $(2.5 \mathrm{~mL})$ was added dimethyl sulfoxide $\left(0.1 \mathrm{~mL}, 1.41 \mathrm{~nm}\right.$ ol) at $-78^{\circ} \mathrm{C}$. and the mixture was stirred at $-78^{\circ} \mathrm{C}$ for $30 \mathrm{~min}$. To this mixture was added a solution of $25(175 \mathrm{mg}, 0.40 \mathrm{mmol})$ in methylene clloride $(2.5 \mathrm{~mL})$, and the reaction mixture was stirred at $-78^{\circ} \mathrm{C}$ for $1 \mathrm{~h}$. After the addition of trietlyy lamine $(0.38 \mathrm{~mL} .2 .73 \mathrm{mmol})$. the nixture was gradually warmed to room temperature. The reaction mixture was quenched with water and then extracted with methylene chloride. The organic layer was dried over anhydrous $\mathrm{MgSO}_{4}$. filtered. and evaporated under reduced pressure. The residue was purified by silica gel column chromatography using hexanes and ethyl acetate $(14: 1)$ as the eluent to give cyclopentenone $14(150 \mathrm{mg}, 86 \%)$ as a colorless oil: $[\alpha]_{5}^{25}+4.8(c 1.06$, $\left.\mathrm{CHCl}_{3}\right)$ : ${ }^{\mathrm{H}} \mathrm{HMR}\left(400 \mathrm{MHz} . \mathrm{CDCl}_{3}\right) \delta 7.66-7.34(\mathrm{~m}, 10 \mathrm{H})$, 6.35 (t. $1 \mathrm{H}, J=2.0 \mathrm{~Hz}), 4.67$ (dd. $1 \mathrm{H}, J=1.6,18.8 \mathrm{~Hz}$ ), 
$4.61(5,1 \mathrm{H}), 4.48(\mathrm{dd}, 1 \mathrm{H} . J=1.6,18.8 \mathrm{~Hz}), 1.41(5.3 \mathrm{H})$, $1.37(\mathrm{~s} .3 \mathrm{H}), 1.20$ (s. $3 \mathrm{H}), 1.07$ (s. $9 \mathrm{H}):{ }^{13} \mathrm{C} \mathrm{NMR}(100 \mathrm{MHz}$. $\left.\mathrm{CDCl}_{3}\right) \partial 204.0,175.9,135.7,135.6,132.8,132.7,130.3$. 128.1. 127.6. 115.2. 84.1, 83.9,62.7, 28.9. 28.4. 26.9. 19.6, 19.5: LRMS $(\mathrm{FAB}+) m / z 437(\mathrm{M}+\mathrm{H})^{-}: \operatorname{HRMS}(\mathrm{FAB}+) m / z$ $\mathrm{C}_{26} \mathrm{H}_{33} \mathrm{O}_{4} \mathrm{Si}(\mathrm{M}+\mathrm{H})^{-}$calcd 437.2148 . obsd 437.2158 .

9-((3aS,4R,6aR)-6-(tert-Butyl-diphenyl-silanyloxymethyl)4,6a-dihydro-2,2,3a-trimethyl-3a $H$-cyclopenta $[d][1,3]$ dioxol4-yl)-6-chlon-9H-jurine (27) and 9-((3aS,6R,6aR)-6-(tert-Butyl-diphenyl-silany lox ymethyl)-6,6a-dihy dro-2,2,3a-trimethyl-3a $H$-cyclopenta[ $d][1,3]$ dioxol-6-yl)-6-chloro-9H-purine (28): To a stirred solution of cyclopentenol 26 (121 mg. 0.28 minol). triphenyl phosphine ( $145 \mathrm{mg} .0 .56 \mathrm{mmol}$ ) and 6-chloropurine ( $86 \mathrm{mg} .0 .56 \mathrm{mmol}$ ) in tetrahydrofiuran $(5 \mathrm{~mL}$ ) was added dropwise diethyl azodicarboxylate $(0.09 \mathrm{~mL}, 0.56 \mathrm{mmol})$ at $0^{\circ} \mathrm{C}$. and the reaction mixture was stirned at room temperature for $1 \mathrm{~h}$. The volatiles were evaporated in vacto and the resulting residue was purified by silica gel column chromatography using hexanes and ethyl acetate $(4.7: 1)$ as the eluent to give the protected 6-chloropurine nucleoside $27(67 \mathrm{mg}, 42 \%$ ) as a colorless oil and migrated product 28 (5 mg, $3 \%$ ) as a colorless oil: compound 27: UV $\left(\mathrm{CH}_{2} \mathrm{Cl}_{2}\right) \lambda_{\max } 266.0 \mathrm{~nm}:[\alpha]_{\mathrm{D}}^{25}-32.8\left(c 0.50 . \mathrm{CHCl}_{3}\right)$ : ${ }^{l} \mathrm{H} \mathrm{NMR}\left(400 \mathrm{MHz}, \mathrm{CDCl}_{3}\right) \delta 8.78(\mathrm{~s}, 1 \mathrm{H}), 7.83(\mathrm{~s}, 1 \mathrm{H}) .7 .70$ $7.36(\mathrm{~m} .10 \mathrm{H}) .5 .89-5.86(\mathrm{~m}, \mathrm{l} \mathrm{H}), 5.75-5.72(\mathrm{~m} . \mathrm{l} \mathrm{H}) .4 .83$ (s. $1 \mathrm{H}), 4.50(\mathrm{~d} 1 \mathrm{H}, J=17.2 \mathrm{~Hz}), 4.46(\mathrm{~d}, 1 \mathrm{H} . J=17.2 \mathrm{~Hz}) .1 .40$ (s. $3 \mathrm{H}) .1 .3+$ (s. $3 \mathrm{H}$ ). 1.08 (s. $9 \mathrm{H}) .0 .91$ (s. $3 \mathrm{H}$ ): ${ }^{13} \mathrm{C}$ NMR $\left(100 \mathrm{MHz}, \mathrm{CDCl}_{\mathfrak{j}}\right) \delta$ 152.7. 152.6. 152.4. 151.5. 143.8. 135.7 . $133.2,133.2 .132 .1 .130 .3,130.2 .128 .1,128.1,121.4,113.4$. $90.0,89.5,67.6,61 .+.29 .1,28.9 .27 .0,20.9,19.5$. LRMS $(\mathrm{FAB}+) m / z 575(\mathrm{M}+\mathrm{H})^{-} ; \mathrm{HRMS}(\mathrm{FAB}+) m / z \mathrm{C}_{31} \mathrm{H}_{36} \mathrm{ClN}_{4} \mathrm{O}_{3} \mathrm{Si}$ $(\mathrm{M}+\mathrm{H})^{+}$calcd 575.2245 obsd 575.2240 : compound $28:{ }^{i} \mathrm{H}$ NMR (500 MHz. $\left.\mathrm{CDCl}_{3}\right) \delta 8.92(5.1 \mathrm{H}), 7.92(5,1 \mathrm{H}) .7 .73-$ $7.40(\mathrm{~m}, 10 \mathrm{H}) .6 .13(\mathrm{t}, 1 \mathrm{H} . J=2.0 \mathrm{~Hz}) .5 .94(\mathrm{~d}, 1 \mathrm{H} . J=2.0 \mathrm{~Hz})$. 4.77 (s. $1 \mathrm{H}) .4 .55-4.47$ (m. $2 \mathrm{H}), 1.63(\mathrm{~s} .3 \mathrm{H}), 1.42(\mathrm{~s} .3 \mathrm{H})$. $1.11(5.9 \mathrm{H}) .0 .93(5.3 \mathrm{H})$.

9-((3aS,4R,6aR)-6-(tert-Butyl-diphenyl-silanyloxymethyl)-4,6a-dihy dmo-2,2,3 a-trimethyl-3 a $H$-cyclopenta[ $d]$ $[1,3]$ dioxol-4-yl)-9H-purin-6-amine (29): A solution of $27(57$ mg. $0.10 \mathrm{mmol}$ ) in methanolic ammonia ( $2 \mathrm{~mL}$ ) was heated to $80^{\circ} \mathrm{C}$ in a glass bomb for $7 \mathrm{~h}$ After cooling to room temperature, the volatiles were removed in vacto. The resulting residue was purified by silica gel column chromatography using hexanes and ethyl acetate (1:2) as the eluent to give protected adenine mlcleoside $29\left(47 \mathrm{mg} .84 \%\right.$ ) as a white solid: $\mathrm{mp} 155.4-157.4^{\circ} \mathrm{C}$; $\mathrm{UV}\left(\mathrm{CH}_{2} \mathrm{Cl}_{2}\right) i_{\text {thax }} 261 \mathrm{~nm} ;[\alpha]_{\mathrm{D}}=27.3\left(c 0.63, \mathrm{CHCl}_{3}\right):{ }^{l} \mathrm{H}$ NMR $\left(400 \mathrm{MHz}, \mathrm{CDCl}_{3}\right) \delta 8.40$ (s. $1 \mathrm{H}$ ). 7.52 (s. $1 \mathrm{H}$ ). 7.70 $7.35(\mathrm{~m}, 10 \mathrm{H}) .5 .88-5.85$ (m. $1 \mathrm{H}) .5 .68-5.65$ (m. $1 \mathrm{H}) .4 .81$ (s. $1 \mathrm{H}) .4 .49$ (d. $1 \mathrm{H}, J=15.6 \mathrm{~Hz}) .4 .44$ (d. $1 \mathrm{H}, J=15.6 \mathrm{~Hz}$ ), 2.13 (br s. $2 \mathrm{H}), 1.39$ (5. $3 \mathrm{H}) .1 .32(\mathrm{~s}, 3 \mathrm{H}) .1 .07$ (s, $9 \mathrm{H}), 0.93$ (s. $3 \mathrm{H}):{ }^{13} \mathrm{C} \mathrm{NMR}\left(100 \mathrm{MHz}, \mathrm{CDCl}_{3}\right)$ oे $155.8,153.7,151.8$. 150.9 .139 .0 .135 .7 . 133.3. 133.3. 130.2. 128.1 112.2, 120.1. $113.1,90.2 .89 .6,66.9,61.4 .29 .2,28.9,27.0 .20 .9,19.5$ : LRMS $(\mathrm{FAB}+) m / z 556(\mathrm{M}+\mathrm{H})^{+}:$HRMS $(\mathrm{FAB}+) m / z$ $\mathrm{C}_{31} \mathrm{H}_{38} \mathrm{~N}_{3} \mathrm{O}_{3} \mathrm{Si}(\mathrm{M}+\mathrm{H})^{-}$calcd 556.2744 . obsd 556.2734 .

(1S,2R,5R)-5-(6-A mino-9H-purin-9-yl)-3-(hydroxymethyl)-1-methylcyclopent-3-ene-1,2-diol (3): To a stirred solution of $29(47 \mathrm{mg} .0 .08 \mathrm{mmol})$ in $\mathrm{MeOH}(0.5 \mathrm{~mL})$ was added $+\mathrm{N}-\mathrm{HCl}(1 \mathrm{~mL})$ at room temperature. After being stirred at the same temperature for $6 \mathrm{~h}$. the reaction mixture was evaporated under reduced pressure until the volumn of solution became $0.5 \mathrm{~mL}$. neutralized with basic resin. and filtered. The filtrate was concentrated in vacuo and the resulting residue was purified by silica gel column chromatography using methylene clloride and $\mathrm{MeOH}(7: 1)$ as the eluent to give $2^{\prime}$ $\beta$-C-methylneplanocin A (3) $(20 \mathrm{mg} .86 \%)$ as a white solid: $\operatorname{mp}=212.5 \cdot 213.7^{\circ} \mathrm{C}$ : UV $(\mathrm{MeOH}) \lambda_{\max } 261.0 \mathrm{~nm}:[\alpha]_{\mathrm{D}}^{35}$ -134.0 (c 0.52, DMF): ${ }^{\mathrm{H}} \mathrm{H}$ NR (500 MHz, CD 3 OD) $\delta 8.22$ (s. I H). 7.98 (s. l H). 5.94 (s. l H). 5.49 (d. I H. $J=1.5 \mathrm{~Hz}$ ). $4.47(\mathrm{~s}, 1 \mathrm{H}),+.36(\mathrm{~d}, 1 \mathrm{H}, J=15.5 \mathrm{~Hz}) .4 .32$ (d. $1 \mathrm{H} . J=$ $15.5 \mathrm{~Hz}), 0.87$ (s. $3 \mathrm{H}):{ }^{13} \mathrm{C}$ NMR (125 MHz, CD $\left.3 \mathrm{OD}\right) \delta 156.2$. $152.7,152.0$. 150.0, 140.0. 121.9, 119.1, 79.3. 79.0,67.1, 59.0. 21.4: LRMS (FAB+) $m / z 278(\mathrm{M}+\mathrm{H})^{+}$

Aclanowledgments. This work was supported by the Korea Research Foundation Grant funded by the Korean Government (KRF-2007-521-E00188).

\section{Refeiences}

1. Murphy, F. A.; Fauquet, C. M.; Bishop, D. H. L.: Ghabrial, S. A.: Jarvis, A. W.; Martelli, G. P.; Mavo, M. A.; Summers, M. D. In Classification and Nomenclature of Iirtses: Sixth Repont of the Intemal Committee on Taxonomy of I intses; Springer-Vielag: Vienna Austria, 1995: $\mathrm{pp}+24-426$

2. Choo, Q. L.: Kulo, G.: Weiner, A. J.: Overby, L. R.: Bradley, D. W: Houghton, M. Science $1989,244,359$.

3. Collier, J.; Chapman, R. BioDrugs 2001, 15, 225

4. Gordon, C. P, Keller, P. A. J. Wed Chent $2005,48,1$.

5. Carroll, S. S.: Tomassini, I. E.: Bossennan, M.: Getty, K.; Stahlhut, M. W: Eldrup, A. B.: Bhat B.: Hall, D.: Simcoe, A. L : LaFemina, R.: Rutkonski, C. A.; Wolanski, B.: Yang, Z,; Migliaccio, G.; De Francesco, R: Kuo, L. C.; MacCoss, M: Olsen, D. B. J. Biol. Chem. 2003, 278, 11979.

6. Pierra, C.: Amador, A.; Benzaria, S.: Cretton-Scott. E.: D Amours, M.; Mao, J.: Mathieu, S.; Moussa, A.; Bridges, E. G.: Standring. D. N.: Sommadossi, J.-P.; Storer, R. Gosselin, G. J. hed Chem. 2006, 19,6614

7. Eldrup, A. B.; Allerson, C. R.; Bennett, C. F.; Bera, S.; Bhat, B.; Bhat, N.; Bosseman, M. R.; Brooks, J.; Burlein, C.; Carroll, S. S.; Cook, P. D.: Getty, K. L.; MacCoss, M.; McMasters, D. R.: Olsen, D. B.: Prakash, T. P.; Prave, M.: Song. Q. Q.: Tomassini, J. E.; Xia, T. J. Hed. Chem. 2004, $47,2283$.

8. Lee, J. A.; Kim, H. O: Tosh, D. K.; Moon, H. R.; Kim, S.; Teong, L. S. Org. Lett. $\mathbf{2 0 0 6}, 8,5081$

9. (a) Yaginuma, S.: Muto, N.; Tsujino, M.; Sudate, Y: Hayashi, M.: Otani, M. J. Antibiot 1981, 34, 359; (b) Hayashi, M.; Yaginuma, S.; Yoshioka, H.; Nakatsu, K. J. Ambiot. 1981, 37,675: (c) Borchardt, R. T.; Keller, B. T.; Patel-Thombre, U. J. Biol. Chem 1984, 259 , 4353, (d) De Clercq, E. Antinicrob. Agents Chemother 1985, 28.84 .

10. Jeong, L. S.; Yoo, S. J.; Lee, K. M.: Koo, M. J.: Choi, W. J.: Kim, H. O.: Moon, H. R.; Lee, M. Y.; Park, T. G.; Lee, S. K. Chun, M. W. J. Hed. Chem 2003 , t6, 201

11. Jeong, L. S.; Zhao, L. X.; Choi, W. T. Pal, S.; Park, Y. H.; Lee, S. K.; Chun, M. W; Lee, Y. B.; Ahn, C. H.; Moon, H. R. Aincleos. Nucleot. Nucleic tcids 2007, 26.713.

12. Yoo, B. N.: Kim, H. O.; Moon, H. R.: Seol, S. K. Jang, S. K.: Lee, K. M.; Jeong, L. S. Bioorg. Wed. Chem. Lett. 2006, 16, 4190.

13. (a) Moon, H. R: Kim, H. O.; Lee, K. M:Chun, M. W. Kim, T. H.; Jeong, L. S. Org. Lent 2002, f, 3501 ; (b) Lee, J. A.; Moon, H. R.; Kim, H. O.; Kim, K. R.; Lee, K. M.: Kim, B. T.: Hwang. K. I.; Chun, M. W. Jacobson, K. A.: Jeong, L. S. J. Org. Chem. 2005, 
70, 5006: (c) Ho, P.-T. Tetrahedron Lett. 1978, 19, 1623.

14. Ohrui, H; Misawa, T; Hori, H; Nishida, Y; Meguro, H. Agric: Biol Chem 1987, 51,81.

15. Whistler, R. L.: BeMiller, I. N. Methods Carbohdr Chem. 1963, 2,484 .

16. Hotchkiss, D. T.: Jenkinson, S. F.: Storer, R: Heinz, T.; Fleet, G. W. J. Tetrahedron Lett. 2006, 47,315.

17. (a) Grubbs, R. H.; Chang, S. Tetrahedron 1998, 54, 4413 ; (b) Grubbs, R. H. Tetrahedron 2004, 60, 7117.

18. Choi, W. T.; Moon, H. R.; Kim, H. O.; Yoo, B. N.: Lee, J. A.; Shin, D. H. Teong, L. S. J. Ong. Chen. 2004, 69, 2634

19. Choi, W. I.: Park, J. G.; Yoo, S. J.; Kim, H. O.: Moon, H. R.: Chun, M. W. Tung, Y. H. . Teong, L. S. J. Org. Chem. 2001, 66, 6490. 20. Crouch, R. D. Tetmahedron 2004, 60,5833.

21. Farras, J.; Serra, C.; Vilarrasa, F. Tetrohedron Lent. 1998, $39,327$.

22. Bartoli, G.: Bosco, M.: Marcantoni, E.: Sambri, L.; Tonegiani,
E. Synlett 1998,209

23. Prakash, C.: Saleh, S.; Blair, I. A. Tetrahedron Lett. 1989, $30,19$. 24. (a) Gemal. A. L.: Luche, I. L. J. Am. Chem. Soc. 1981, 103, 5454 . (b) Luche, J. L. J. Am. Chem. Soc. 1978, 100, 2226.

25. (a) Mitsunobu, O. Synthesis 1981, l; (b) Teong. L. S.: Yoo, S. T.; Moon, H. R.: Kin, Y. H.: Chun, M. W. J. Chem. Soc. Pertin Trans I 1998. 3325: (c) Kim. K. R.: Park. A.-Y.: Lee. H.-R: Kang. J.A.; Kim, W. H.; Chun, P.; Bae, J. H.; Jeong, L. S.; Moon, H. R. Bull. Konem Chent. Soc. 2008, 29, 1977; (d) Park, A.-Y.; Kim, K. R.: Lee, H.-R.: Kang, T.-A.: Kim, W. H.: Chun, P.: Almad, P: Jeong, L. S.; Moon, H. R. Bull Korean Chem. Soc. 2008, $29,2487$.

26. Liao, X.; Butora, G.; Olsen, D. B.; Carroll, S. S.; McMasters, D. R.: Leone, T. F.; Stahlhut, M.; Doss, G. A.; Yang. L.; MacCoss, M. Tetrahedron Lett. $2008,49,4149$.

27. Hotchkiss, D. J.: Kato, A.: Odell, B.: Claridge, T. D. W.: Fleet, G. W. I. Tetrahedron: Asmm 2007, 18, 500 . 